\title{
EVALUATION AND RESEARCH EXPERIENCE OF THE OPERATIONAL CONTROL OF MAGNITOGORSK HEAT SUPPLY SYSTEM
}

\author{
S.A. Golyak, sgavv@mail.ru \\ Nosov Magnitogorsk State Technical University, Magnitogorsk, Russian Federation
}

\begin{abstract}
The article considers a number of operational control aspects of Magnitogorsk city heat supply system. The development of the industrial city's heat supply system, as well as its operational control, updating and restructuring are evaluated both in their own scope and in the advancement of the whole energy generation in Russia. The results of the analytic and applied research of the operational control of the heat supply system are displayed. The results obtained can be assessed in the operational control adjustment of the heat supply system of the Magnitogorsk city and PJSC "Magnitogorsk Iron and Steel Works", as well as in its further development and automation.

Keywords: operational control of functioning, centralized heat supply systems, district heating.
\end{abstract}

\section{Introduction}

The Russian Federation geographically spans about a sixth part of the Earth terrain. The utmost part of its territory is located in the severe climatic conditions. In order to provide a stable functioning of the centralized heat supply system and its operational control in the climatic conditions of Russia it is being spent up about one third part of all fuel resources mined and produced in the country.

In fact, it means that every third ton of coal, fuel oil, peat, every third cubic meter of gas mined and produced in Russia is spent up for functioning of its centralized heat supply system.

Centralized heat supply systems efficiency analysis shows a deterioration of its operational functioning in Russia over the last several heat supply seasons. Experts say that industry can face a deep crisis in case of its aggravation and absence of a long-term planning [1, 2, 4-19].

For operational functioning of the centralized heat supply system of Moscow (e.g.) during a winter period hundreds of railway wagons of coal, fuel oil, peat, abundant cubic meters of gas are to be daily consumed. Actually, if being compared to the system of Moscow and its heat power output, the centralized heat supply system of Magnitogorsk also requires relatively considerable amount of fuel resources in order to afford its stable operational functioning.

\section{Efficiency analysis of the operational control of centralized heat supply}

\section{in the Russian Federation}

According to some experts, the problem of heat supply in Russia became precarious by the end of heat supply period of 2015-2016 [5, 6, 10, 12, 15]. A number of accidents were increasing, and both consumers and generating companies were dissatisfied with tariffs of heat supply [12, 16-18, 25].

However, this assessment, according to some specialists and market analysts, is rather restricted. The stated fact, for instance, is that in St. Petersburg a worn out level of heat supply piping networks is not more than $30 \%$. Nonetheless, in the course of the first month of 2016 a number of accidents had happened on municipal heat supply systems. Some of them took place within a limited heat supply area of Vasilyevsky Island. This area includes 673 buildings, presented by 500 residential houses and nine hospitals, with a maternity hospital and a children hospital among them.

According to some estimation, companies producing thermal energy face a progressive ageing of equipment. As a consequence, the reliable operation of these companies is under growing risks. In order to reduce these risks, it is necessary to increase maintenance expenditures for heat supply piping networks, as well as for boilerhouses and power plants. According to an ongoing upgrading process this will require an extension of revenues generated on the electricity market. It must be emphasized that similar procedures are to be implemented in practice repeatedly on a regular basis. As statistics shows, if no corrective technical and economical procedures were taken in due time, it would seriously increase in a number of accidents, especially in respect to the piping networks. 


\section{Управление в технических системах}

The number of emergencies on the main heat piping networks, maintained by organizations affiliated to the heat and electric power industry, had increased by $16 \%$ during the heat supply period of 2014-2015, if compared to that of 2013-2014, amassing to the number of 1122. Among them 53 situations were accompanied by heat supply interruptions lasting more than 24 hours. Almost $70 \%$ of accidents have occurred on the main heat piping networks with an exceeded normative time period of operational control (i.e. more than 25 years). A number of such networks had grown by $3.6 \%$. Meanwhile heat supply industry specialists accentuate the fact that these statistics reflect only major accidents in backbone heat supply piping networks. If actual and probably much more extended length of thermal piping networks and their presumably grater deterioration would have been taken into consideration, then volumes of technological breakdowns, leading to local heat supply interruptions, could have been possibly grater by an order [7].

The following main priorities were defined for medium term development of domestic energy supply sector:

- energy saving procedures for the processes of energy generation, supply and consumption;

- energy consumption efficiency increasing;

- improvement of the national energy balance of the Russian Federation to be performed by the federal government;

- safekeeping of energy supply stability;

- improvement of the fuel and energy complex structure;

- enhancement of technical and ecological safety procedures of the energy production industry;

- energy production growth as a factor of foreign and domestic policy.

Therefore, an effective development of the national economy is impossible without strengthening of the organizational, technical, financial and economic basis of the country's fuel and energy sector. The structure of Russian thermal loads is given in Table 1 .

Structure of Russian heat loads

Table 1

\begin{tabular}{|l|c|c|c|}
\hline \multicolumn{1}{|c|}{ Sources of thermal energy } & $\begin{array}{c}\text { Volumes } \\
\text { of production, } \\
\times 10^{6} \mathrm{Gcal}\end{array}$ & $\begin{array}{c}\% \text { in total } \\
\text { volume }\end{array}$ & $\begin{array}{c}\% \text { in each } \\
\text { sector }\end{array}$ \\
\hline Total & 2100 & 100 & \\
\hline 1. Centralized, including: & 1430 & 68 & 100 \\
\hline $\begin{array}{l}\text { - thermal electric power stations, thermal electric } \\
\text { stations of the federal level }\end{array}$ & 710 & 34 & 49 \\
\hline - boiler stations with load more than 20 Gcal/h & 720 & 34 & 51 \\
\hline 2. Decentralized, including: & 600 & 29 & 100 \\
\hline - boiler stations with load less than 20 Gcal/h & 260 & 13 & 43 \\
\hline - autonomous and individual & 340 & 16 & 57 \\
\hline $\begin{array}{l}\text { 3. Other (recycling installations, electric boilers, } \\
\text { nuclear) }\end{array}$ & 70 & 3 & 100 \\
\hline
\end{tabular}

Meanwhile the task of national energy saving policy practical implementation should be considered in a careful and detailed manner. The same approaches to the development district energy supply should be implemented in industrial cities because of the following reasons:

- the heat supply systems of industrial cities like Magnitogorsk include both industrial and municipal heat supply networks;

- industrial cities possess well-developed sources of heat supply;

- the power supply complex of industrial cities often implement cogeneration techniques.

It is worthwhile noting that at the beginning of the 2000s the Fuel and Energy Complex (FEC) of the Russian Federation had fulfilled in general the governmental task of increasing the extraction of primary fuel and energy resources. Herewith it had stabilized modus vivendi of the economy and ensured its planned growth.

However, the country has also endured series of the FEC unsolved difficulties:

- high deterioration of fixed assets; 
- insufficient level of capital investments;

- distorted price ratio between interchangeable power resources;

- sharp worsening of raw-material basis in terms of quantity and quality;

- low efficiency of market infrastructure and absence of civilized competitive power generating market;

- shortcomings in efficiency of management of the branches of the FEC in state ownership;

- low level of revenues from domestic and world energy markets;

- shortage of fuel and heat supply in a number of Russian regions, especially in the Far East (e.g. Primorye and Chita regions).

The task of providing a reliable heat supply, especially, for district heating purposes during autumnwinter period has an actual social significance. Total analysis and evaluation of problems of heat supply require active cooperation between FEC and public utilities.

The majority of metropolitan areas in Russia are supplied by thermal electric power stations, owned by private generating companies. In addition, there are industrial cogeneration plants and boiler-houses, associated with industrial enterprises. These industrial sources produce heat-carrier and electric energy to supply corresponding enterprise facilities, additionally providing heat supply to adjoining residential areas, mainly inhabited by the employees of those enterprises. This structure describes the city of Magnitogorsk as well (Fig. 1). In addition, a number of independent individual boiler-houses mounted inside the residential or office buildings or supplying several blocks of houses, increase significantly over the recent years.

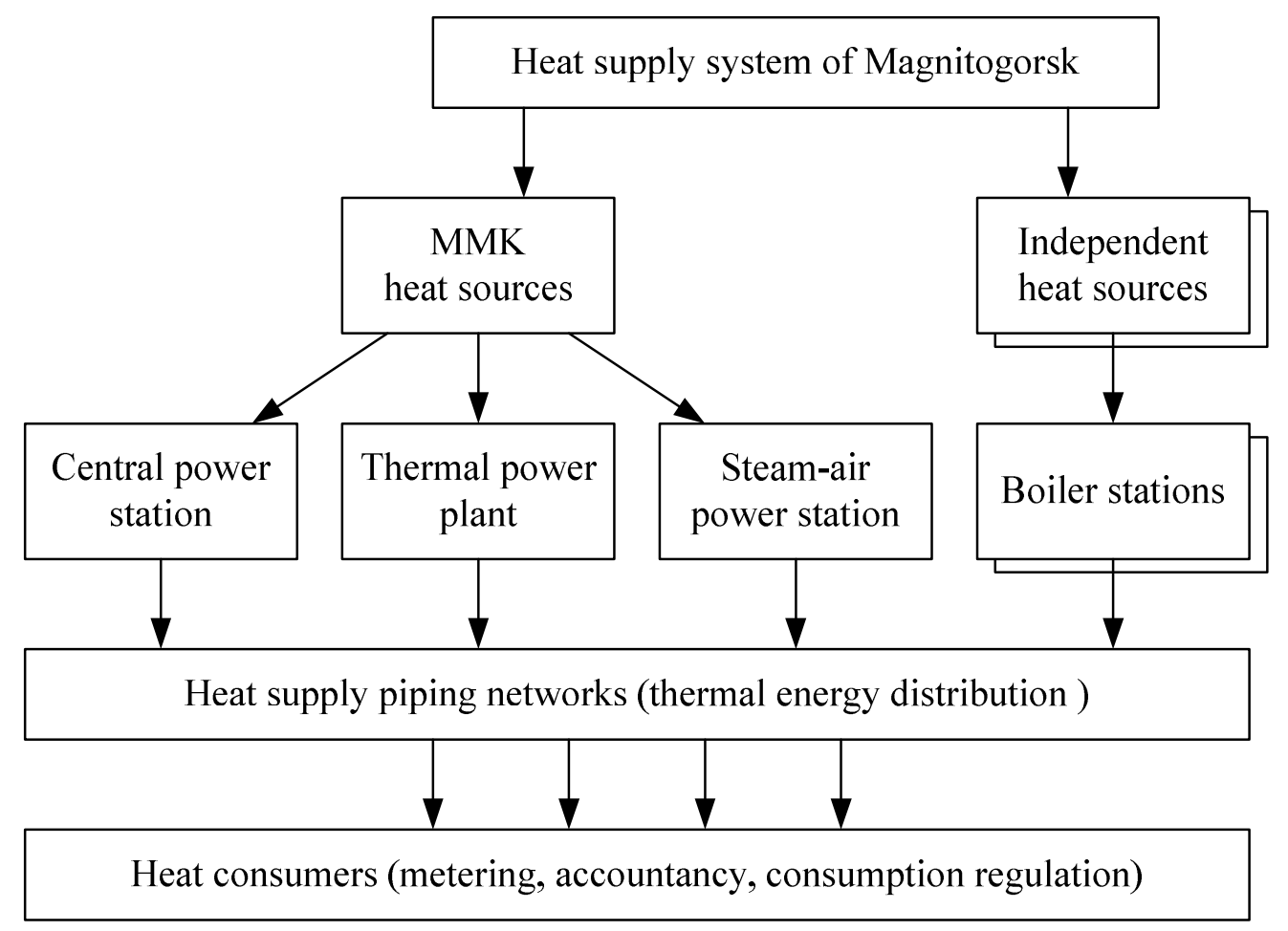

Fig. 1. Operation control structure of Magnitogorsk heat supply system

Centralized heat supply systems provide heat-carrier for about $75 \%$ of all consumers, including rural settlements. About $35 \%$ of heat energy is provided by cogeneration plants. In total, large cogeneration systems produce about 1.5 million Gcal per year. Hence, large heat supply piping systems are function mainly in cities with a rated thermal load more than $500 \mathrm{Gcal} / \mathrm{h}(580 \mathrm{MW}$ (thermal)). The larger is the city, the more powerful is its centralized heat supply piping system. In majority of large cities centralized heat supply piping systems provide heat-carrier to $70-95 \%$ of available housing stock. Their share in total thermal capacity of all heat sources is around $70 \%$ (refer to Table 2). However, the majority of energy saving capabilities is located at consumers' side and in engineering networks. It includes $25-60 \%$ of the heat and $15-25 \%$ of the electrical energy. 
Share in total thermal capacity of thermal electric power stations for general use

\begin{tabular}{|l|c|c|c|c|c|}
\hline $\begin{array}{c}\text { Thermal capacity } \\
\text { load, Gcal/h }\end{array}$ & Less than 100 & 100 to 500 & 500 to 1000 & 1000 to 3500 & More than 3500 \\
\hline Number of cities & 2345 & 528 & 95 & 74 & 36 \\
\hline Share in total load & $12 \%$ & $18 \%$ & $10 \%$ & $21 \%$ & $39 \%$ \\
\hline
\end{tabular}

In our view, main objectives of country's municipal heat supply middle-term development are to be the following:

- to gather and analyze actual information on technical conditions, efficiency and reliability of heat supply area of our country;

- to assess the current situation in the area of heat supply in Russia and to define improvement priorities;

- to formulate an efficiency improving conception in terms of legislative, regulatory, administrative, financial, economic, organizational and technical maintenance.

Country's municipal data analyze, including that of Magnitogorsk, points toward existence of a large number of broad-spectrum municipal and district problems concerning heat supply infrastructure. Total length of heat supply piping networks in Russia by the end of 2013 amounted to $168,000 \mathrm{~km}$ in double-tube terms. As it is now, the stretch of end to end of $48,000 \mathrm{~km}(29 \%)$ need to be repaired and reconstructed. The length of heat supply piping networks with $100 \%$ of physical deterioration is more than $32,000 \mathrm{~km}(19 \%)$.

In order to avoid critical operational risks and to attain an average worsening age of heat supply piping networks of other developed countries, the annual piping networks updating necessary rate should not be at least 3-4\%. However, actual rate, in fact, does not exceed $1-1.5 \%$ per year of the total length of networks. The current situation leads to an ageing of fixed assets and to a negative impact on energy facilities' level of safety in the winter period. The number of accidents on heat supply piping systems is much higher than on similar systems of other countries $[1,2,5,6]$. Regulation in this sphere is attributed mainly to municipal authorities, though municipal authorities are in most cases not in a position to make any strategic decisions. Municipal authorities can only resolve short-term tasks.

So, every heat supply organization is administrated on the individual basis. Actually there is no single center of responsibility before the consumer. Finally, nobody is responsible for quality and reliability of heat supply. And, as a matter of fact, it is in nobody's interest to share the load of responsibility for heat supply inside a district, since the effect of savings is withdrawn by the administrator [5-15, 18-24].

Until there is no a single center of responsibility before the consumer, the consumer pays to any interim virtual heat supply organizations irrespectively of their number and standing. The state authorities only restrict a growth of price rates, but due to the lack of clear price indicators it does not protect the consumer. As a result, tariffs are steadily growing higher, but investments are coming in slowly. [1, 9, 12].

\section{Efficiency analysis of the operational control of centralized heat supply in Magnitogorsk}

During 1990s the centralized heat supply piping system of Magnitogorsk city faced the same problems as the whole country does [1-17, 23-25]. Development of the production basis of the PJSC "Magnitogorsk Iron and Steel Works" (also known as MMK) and growth of the city resulted in a construction of joint centralized heat supply piping system.

The history of the centralized heat supply system of Magnitogorsk has its origin in establishment and development of the energy generating system of the MMK. It is based on the central electricity-heat station of the MMK.

Magnitogorsk with its population of about 420,000 people is located in the area with a moderate climate. Heat supply season continues from October to May (218 days). Average monthly air temperature in December-February is within a range from $\left(-11^{\circ} \mathrm{C}\right)$ down to $\left(-25 \ldots-35^{\circ} \mathrm{C}\right)$.

About $90 \%$ of municipal consumers receive heat from the centralized heat supply piping networks, where $63 \%$ of heat comes from the heat electrical central, the central electricity heat station, and the steam-air pumping station of the MMK. The other part of heat is produced by three boiler stations. Total heat load is about $1,200 \mathrm{Gcal} / \mathrm{h}$. Total annual heat consumption, including losses of heat, is about 4 million Gcal. A considerable share within utilities payments (viz. 53-67\%) stands for heat supply 
costs during heat supply period. It includes payments for centralized heat supply and hot water supply $[11,12,15,24]$.

As the research results show, further development of the municipal and industry energy production in Magnitogorsk is going in accordance with a power strategy implementation of the country [5-9, 12-19, 21-25]. Structure of distribution of heat supply load in Magnitogorsk from municipal and district sources in the housing and communal services is presented in Table 3.

Structure of distribution of heat supply load in Magnitogorsk from municipal and district sources in the housing and communal services

\begin{tabular}{|l|c|c|c|c|}
\hline \multirow{2}{*}{ Main consumers } & \multirow{2}{*}{ Units } & \multicolumn{3}{|c|}{ Total heat supply sources' loads } \\
\cline { 3 - 5 } & & Municipal sources & District sources & Total \\
\hline \multirow{2}{*}{ Municipal housing fund } & $\mathrm{Gcal} / \mathrm{h}$ & 270.04 & 417.81 & 687.85 \\
\cline { 2 - 5 } & $\%$ & 22.2 & 34.4 & 56.6 \\
\hline \multirow{2}{*}{ Budgetary organizations } & $\mathrm{Gcal} / \mathrm{h}$ & 50.53 & 414.61 & 465.14 \\
\cline { 2 - 5 } & $\%$ & 4.16 & 34.12 & 38.28 \\
\hline \multirow{2}{*}{ Private sector } & $\mathrm{Gcal} / \mathrm{h}$ & 61.74 & 0.26 & 62.0 \\
\cline { 2 - 5 } & $\%$ & 5.08 & 0.02 & 5.10 \\
\hline \multirow{2}{*}{ Total } & $\mathrm{Gcal} / \mathrm{h}$ & 382.32 & 832.68 & 1215 \\
\cline { 2 - 5 } & $\%$ & 31.47 & 68.53 & 100 \\
\hline
\end{tabular}

As much as $71 \%$ of the total heat load produced by municipal boiler-houses is consumed by apartment buildings. It consumes $51 \%$ of the total heat load of all heat sources. The budgetary organizations consume other $34 \%$ of the load related to the departmental sources of thermal energy. The structure of heat consumers in Magnitogorsk are presented in Fig. 2.

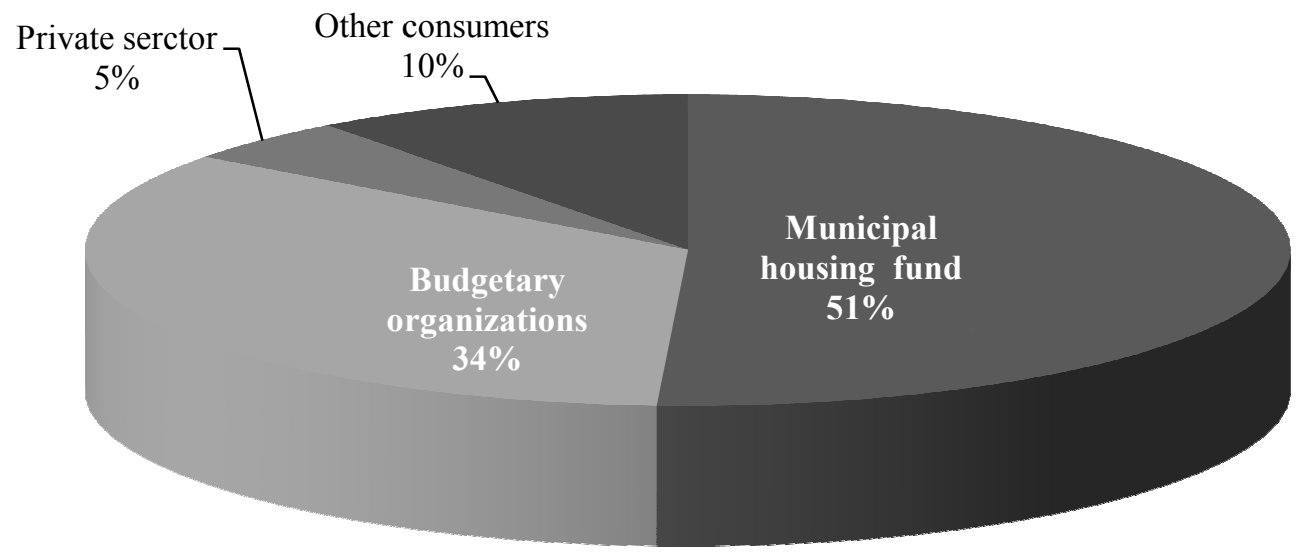

Fig. 2. Structure of Magnitogorsk heat consumers

The current situation in the thermal power complex of the MMK and of the industrial city Magnitogorsk has a number of functional deficiencies that need to be eliminated. One of the key issues here is to assure a balance of interests between the thermal energy producers. They are power generating plants of the MMK and the cogeneration sources of heat supply of Magnitogorsk.

Currently the MMK, as a commercial body, is making every effort to reduce expenses of its metallurgical products. The significant part of expenses is attributed to electrical energy consumption. This makes the power stations of the MMK to carry out energy generating regimes in accordance with the following criterion: maximum generation of electric power with minimum consumption of fuel resources.

Certain results are achieved by reducing heat-carrier temperature chart. But from the beginning of its operation heat supply piping systems of Magnitogorsk was designed to function according to the high temperature chart of $150-70^{\circ} \mathrm{C}$. That is one of the major problems that require a mutually acceptable solution from the authorities. 


\section{Управление в технических системах}

An objective analysis of the operation control of Magnitogorsk heat supply piping system's technical parameters is required in order to solve the above problems. Primarily, it is required to estimate remaining lifetime in the practice of thermal energy consumption. On this basis researchers and production stuff have to suggest an effective solution that will balance interests of the energy supply companies of the MMK and those of the municipal consumers of Magnitogorsk [3, 4, 11-14, 17, 18, 24]. An absence of a positive approach toward clarification of this issue would lead to unreasonable economic losses on both sides. On the part of the MMK an upturn of the cost of energy in the total cost of the final metallurgical products is observed. On the side of the consumers a weakening of the housing comfort is noticed due to inappropriate temperature and deficit of the supplied thermal energy.

At the same time the experience of the advanced industrial countries shows that, under similar conditions of the market economy and comparable technical parameters in the energy sector, mutually beneficial agreement between suppliers and consumers of energy resources can be achieved. In that regard the low-temperature heat supply experience of Denmark can be mentioned. The matter is that the temperature of the heat flow in the whole system is reduced as far as possible. At the same time all parameters of the heat supply system are under current operational control and being regulated. Meanwhile the consumers of thermal energy are fully adapted to the parameters of the low-temperature heat supply [3].

The following advantages of the low-temperature heat-carrier are:

- reducing heat losses within piping networks;

- increasing electric power output of thermal power stations;

- reducing fuel consumption;

- creating preconditions for alternative heat energy sources implementation.

Therefore, a lowering of heat-carrier temperature by $10^{\circ} \mathrm{C}$ results in fuel consumption decrease by $0.5-1 \%$ according to the Danish specialists. At the same time the output of electric energy on thermal power stations rises by $0.2-0.3 \%$. Consequently, reducing heat-carrier temperature by $10^{\circ} \mathrm{C}$ diminishes heat losses in heat supply piping networks by $0.33 \%$ in relation to the entire heat supply volume. The heat-carrier temperature in Denmark is being kept less than $70^{\circ} \mathrm{C}$ when the outdoor temperature is about $-12^{\circ} \mathrm{C}$. The level of heat losses in heat supply piping networks is about $18 \%$, and the level of heat-carrier leakage is under $2 \%$.

Nevertheless, a straight alignment of domestic heat supply technologies to contours of district heat supply technologies of the European countries irrespectively to the local climatic and technical conditions of Magnitogorsk is inappropriate in our opinion. One of the central issues here is a reasonable tariff policy that enables an introduction of energy-efficient technologies by means of an optimal carrying of the heat supply operational control.

The existing regulatory framework allows including investment costs into the customer price. These investment costs countervailed by energy-saving activities will not lead to sufficient consumer price increase. At the same time it boosts energy-saving activities development. As for today, however, these possibilities are not fully realized, making them issues to be clarified.

\section{Conclusions}

1. Formation and development of district heat supply piping systems of Magnitogorsk and the whole Russia have both their own and similar features. The difference between them is due to a significant variance of climatic conditions in various regions of the country.

2. An overall assessment of the country's centralized heat supply system actual state is required in relation to legislative, regulatory, administrative, financial, economic, organizational aspects and technical maintenance. It can facilitate a correct definition of priorities in terms of heat supply system improvement.

3. In order to promote further development of local heat supply piping system it is necessary to gather and analyze the operational control information including technical conditions, efficiency and functioning reliability of the heat supply in Russia.

4. Further research activities have to be directed toward finding a particular balance of interests between industrial and municipal sources of centralized heat supply and assurance of its accurate implementation.

5. Solutions of numerous operational problems in centralized heat supply may be found by implementing low temperature technologies of heat supply with an appropriately adjusted operational control. 
6. Evaluation and research experience indicate that direct rearrangement of domestic heat supply technologies to the features of district heat supply technologies of the European countries irrespectively to the local climatic and technical conditions cannot result in viable solution.

7. As our research experience shows, only detailed scientific research will lead to formulating reliable criterions to define correct technical and economic decisions in the area of heat supply and its operational control. This is the right way of solving problems of district heat supply systems of industrial cities, namely of Magnitogorsk.

\section{References}

1. Basargin V. Prichina avariy - vetkhost' kommunal'nogo fonda [The Reason of Accidents is Deterioration of Municipal Fund]. Rosbalt, 24 December, 2009. Available at: http://www.rosbalt.ru/main/2009/12/24/700069.html.

2. Pchelintsev O.S., Minchenko M.M. Konkurentosposobnost' i modernizatsiya ekonomiki [Infrastructure Prerequisites of Regional Economics Restructuring]. Moscow, High School of Economics Publ., 2004. 258 p.

3. Andersen N. [End-Users Prefer Low Temperature District Heating]. News from DBDH, 1999, no. 4, pp. 30-31. (in Russ.)

4. [Micro-Turbines in Russian Co-Generation Practice]. Industrial and Heating Boiler Houses and Mini-HEPS, 2012, no. 4 (14). (in Russ.)

5. Mikhaylov S.A., Klimenko A.V., Izvekov A.V., Manchkha S.P., Malafeev V.A., Semenov V.G., Sidorov A.L., Berner M.S. Kontseptsiya razvitiya teplosnabzheniya v Rossii, vklyuchaya kommunal'nuyu energetiku, na srednesrochnuyu perspektivu [Concept of a Middle-Term Development of the Centralized Heat Supply System of Russia, Including the Municipal Energy System]. Moscow, 2002. Available at: http://www.rosteplo.ru/Npb_files/npb_shablon.php?id=27.

6. Bol'shinstvo kommunalnykh avariy svyazano s nedostatkom investitsiy $v$ ZhKKh [The Majority of Municipal Emergencies are Caused by Insufficient Investments in Public Utilities Sector]. RIA-Novosti, 16 March 2010. Available at: https://ria.ru/society/20100316/214683088.html.

7. Prognoz chrezvychaynoy obstanovki v Rossiyskoy Federatsii na 2017 god [Prognosis of Emergency Situation in Russia for 2017]. Moscow: EMERCOM of Russia, 2016. Available at: http://www.mchs.gov.ru/upload/site1/Prognoz_na_2017_god_gotovyy.pdf.

8. Golyak S.A. [Purpose and Structure of Automation Control Systems in the Mining Industry]. Materialy chetvertoy vserossiyskoy nauch.-tekhn. konf. "Informatsionnyye tekhnologii v nauke. proyektirovanii i proizvodstve" [The 4-th Russian scientific-technical conf.: Information Technologies in Science, Projecting and Production]. Nizhny Novgorod, NGTU Publ., 2002, vol. 1, pp. 12-15. (in Russ.)

9. Artem'ev I. FAS khochet zamorozit' tarify ZhKKh na pyat' let [FAS Intends to Stop Utility Tariffs] Gazeta.ru, 16.11.16. Available at: https://www.gazeta.ru/business/news/2016/11/16/ n_9341555.shtml.

10. Rosteplo.ru. Informatsionnaia sistema po teplosnabzheniyu, 2003-2016. [Information System for Heat Supply]. Available at: http: www.rosteplo.ru.

11. Apartsev M.M. Naladka vodyanykh sistem tsentralizovannogo teplosnabzheniya [Adjustment of Water Systems in Centralized Heat Supply]. Moscow, Energoatomizdat Publ., 1983. 204 p.

12. Golyak S.A., Kartashova E.A. [Price Formation in Utility Sector]. From Young Researches - to the Future of Science, 2004, pp. 90-93. (in Russ.)

13. Arzamastsev A.A. [Innovative Technologies of Heat Supply in Housing Sector]. Economics and Modern Management: Theory and Practice, 2012, pp. 25-29. (in Russ.)

14. Golyak S.A. [Modern Information Technologies for Operation Efficiency Improvement at Heat and Gas Supply and Ventilation]. Sovremennoye stroitel'stvo i obucheniye studentov stroitel'nykh $i$ arkhitekturnykh spetsialnostey: III region. nauch.-metod. konf. [Modern Building Construction and Civil Engiveering Education. The 3rd Regional Academic Conference]. Magnitogorsk, MGTU Publ., 2004, pp. 14-15.

15. Sharapov V.I, Rotov P.V. Regulirovanie nagruzki system teplosnabzheniya [Load Regulation of Heat Supply Systems]. Moscow, Novosti Teplosnabzheniya Publ., 2007. 162 p.

16. Energoeffectivnaya Rossiya [Energy Effective Russia]. Available at: http://energosber.info/ articles/energy-tools. 


\title{
Управление в технических системах
}

17. Lisienko V.G. Sovershenstvovanie i povyshenie effektivnosti energotechnologiy i proizvodstv [Improvement End Increasing of Efficiency of Energy Technologies and Production]. Ekaterinburg, UrFU Publ., 2013. 592 p.

18. Tipovaya instruktsiya po technicheskoy ekspluatatsii sistem transporta $i$ raspredeleniya teplovoy energii (teplovykh setey). [Typical Instruction on Technical Operation of Systems of Transport and of Distribution of Thermal Energy (Thermal Networks). RD 153-340-20.507-98, ORGRES, 1999.

19. Gromov N.K. Gorodskie teplofikatsionnye sistemy [Urban Electric and Heat Supply Systems]. Moscow, Energia Publ., 1974. 256 p.

20. Safonov A.P. Avtomatizatsiya sistem tsentralizovannogo teplosnabzheniya [Automation of Centralized Heat Supply Systems]. Moscow, Energia Publ., 1974. 272 p.

21. Sokolov E.Ya. Teplofikatsiya i teplovye seti [Electric and Heat Supply Networks]. Text Book for Universities. 7-th ed. Moscow, MEI Publ., 2001. 472 p.

22. Zinger N.M. Raschet i modelirovanie gidravlicheskikh rezhimov teplovykh setei [Calculation and Modeling of Hydraulic Regimes in Heat Supply Networks]. Moscow-Saint Petersburg, Energy Publ., 1964. 184 p.

23. Golyak, S.A., Gavrilova T.O. [Improvement of Efficiency of Heat Generator by Means of Lessening of Cavitation]. Chief Power Engineer, 2015, no. 2. pp. 44-50. (in Russ.)

24. Golyak S.A., Pavlova G.A., Simonov O.N. [Energy Saving in Heat Supply Systems of Industrial Companies]. Civil Engineering and Education, 2000, iss. 4, pp. 170-171. (in Russ.)

25. Golyak S.A., Gavey O.F. [Temperature Reducing in Heat Supply Systems of Russia: Pro et Contra]. Energy Saving, 2012, vol. 3, no. 3, pp. 42-47. (in Russ.)

Received 29 August 2017

\section{Удк 628.8}

DOI: $10.14529 / \mathrm{ctcr} 170405$

\section{ОЦЕНКА И ОПЫТ ИССЛЕДОВАНИЙ ОПЕРАЦИОННОГО КОНТРОЛЯ СИСТЕМЫ ТЕПЛОСНАБЖЕНИЯ ГОРОДА МАГНИТОГОРСКА}

\author{
C.А. Голяк \\ Магнитогорский государственный технический университет им. Г.И. Носова, \\ г. Магнитогорск, Россия
}

\begin{abstract}
Рассматривается ряд аспектов операционного контроля системы теплоснабжения индустриального города Магнитогорска Челябинской области. Развитию системы теплоснабжения города, её модернизации и реструктуризации дана оценка как в своём собственном контексте, так и в общем представлении о развитии системы генерации энергетических ресурсов России. Представлены результаты аналитических и прикладных исследований операционного контроля функционирования системы теплоснабжения. Полученные результаты могут быть учтены как в процессе операционного контроля системы теплоснабжения города и ОАО «ММК», так и при её дальнейшем развитии и автоматизации.

Ключевые слова: операционный контроль, системы цุентрализованного теплоснабжения, теплоснабжение городов.
\end{abstract}

\section{Литература}

1. Басаргин, В. Причина аварий - ветхость коммунального фонда / В. Басаргин // Росбалт. 24 декабря 2009. - http://www.rosbalt.ru/main.

2. Пчелинщев, О.С. Инфраструктурные предпосылки реструктуризачии региональной экономики / О.С. Пчелинщев, М.М. Минченко // Конкурентоспособность и модернизация экономики. - М.: ГУ ВШЭ, 2004. - 258 c. 
3. Андерсен, Н. Потребители на местах предпочитают низкотемпературное теплоснабжение / Н. Андерсен // Новости DВDН (Дания). - 1999. - № 4. - С. 30-31.

4. Микротурбины в российской практике когенеращии // Промышленные и отопительные котельные и мини-ТЭЦ. - 2012. - № 4 (14).

5. Концепция развития теплоснабжения в России, включая коммунальную энергетику, на среднесрочную перспективу / С.А.Михайлов, А.В. Клименко, А.В. Извеков и др. - М., 2002. http://www.rosteplo.ru/Npb_files/npb_shablon.php?id=27.

6. Большинство коммунальных аварий связано с недостатком инвестиций в ЖКХ // РИА Новости. - 16 марта 2010. - https://ria.ru/society/20100316/214683088.html.

7. Прогноз чрезвычайной обстановки в Российской Федерации на 2017 год. - М.: МЧС Росcuu,. 2016. - http://www.mchs.gov.ru/upload/site1/Prognoz_na_2017_god_gotovyy.pdf.

8. Голяк, С.А. Назначение и структура автоматизированных систем управления в горнодобывающем производстве / С.А. Голяк // Материаль четвертой всерос. науч.-техн. конф. «Информационные технологии в науке, проектировании и производстве». - Нижний Новгород: НГТУ, 2002. - Ч. I. - C. 12-15.

9. ФАС хочет заморозить тарифы ЖКХ на пять лет / И. Артемьев // Газета.rи. - 16.11.16. https://www.gazeta.ru/business/news/2016/11/16/n_9341555.shtml.

10. РосТепло.ги. Информационная система по теплоснабжению, 2003-2016. http://www.rosteplo.ru/

11. Апариев, М.М. Наладка водяных систем иентрализованного теплоснабжения / М.М. Апариев. - М.: Энергоатомиздат, 1983. - 204 с.

12. Голяк, С.А. Ценообразование в жилищном хозяйстве / С.А. Голяк, Е.А. Карташева // Студенческая молодежь - науке будущего: сб. тр. - Магнитогорск: МГТУ, 2004. - С. 90-93.

13. Арзамасиев, А.А. Инновачионные технологии теплоснабжения в сфере ЖКХ / А.А. Арзамасиев // Экономика и современный менеджмент: теория и практика: сб. ст. по материалам ХVI междунар. науч.-практ. конф. - Новосибирск: СибАК, 2012. - С. 23-29.

14. Голяк, С.А. Современные информационные технологии в повышении эффективности эксплуатации систем теплогазоснабжения и вентиляиии / С.А. Голяк // Современное строительство и обучение студентов строительных и архитектурных специальностей: III регион. науч.-метод. конф. - Магнитогорск: МГТУ, 2004. - С. 14-15.

15. Шарапов, В.И. Регулирование нагрузки систем теплоснабжения: моногр. / В.И. Шарапов, П.В. Ротов. - М.: Новости теплоснабжения, 2007. - 162 c.

16. Энергоэффективная Россия. Информационный портал. - http://energosber.info/articles/ energy-tools.

17. Лисиенко, В.Г. Совершенствование и повышение эффективности энерготехнологий и производств. Т.2. Кн. 1: Новые способы, модельные и экспериментальные исследования: моногр. / В.Г. Лисиенко. - Екатеринбург: УрФУ, 2013. - 592 с.

18. РД 153-340-20.507-98. Типовая инструкция по технической эксплуатации систем транспорта и распределения тепловой энергии (тепловых сетей). - М.: ОРГРЭС, 1999.

19. Громов, Н.К. Городские теплофикационные системы. - М.: Энергия, 1974. - 256 c.

20. Сафонов, А.П. Автоматизация систем централизованного теплоснабжения. - М.: Энергия, 1974. -272 c.

21. Соколов, Е.Я. Теплофикация и тепловые сети: учеб. для вузов. - 7-е изд., стереот. - М.: Изд-во МЭИ, 2001. - 472 с.

22. Зингер, Н.М. Расчет и моделирование гидравлических режсимов тепловых сетей. - М.; Л.: Энергия, 1964. - $184 c$.

23. Голяк, С.А. Повышение эффективности теплогенератора с учетом снижения кавитаиии / С.А. Голяк, Т.О. Гаврилова // Главный энергетик. - 2015. - № 2. - С. 44-50.

24. Голяк, С.А. Энергосбережение в системах теплоснабжения промышленных предприятий / С.А. Голяк, Г.А. Павлова, О.Н. Симонов // Строительство и образование: сб. тр. - Екатеринбург: УГТУ-УПИ, 2000. - Вып. 4. - С. 170-171.

25. Голяк, С.А. Снижение температуры теплоносителя в системах теплоснабжения России: за и против / С.А. Голяк, О.Ф. Гавей // Энергосбережение, 2012. - Т. 3, № 3. - С. 42-47. 


\section{Управление в технических системах}

Голяк Сергей Алексеевич, д-р техн. наук, профессор кафедры управления недвижимостью и инженерных систем, Магнитогорский государственный технический университет им. Г.И. Носова; sgavv@mail.ru.

Поступила в редакцию 29 августа 2017 2.

\section{ОБРАЗЕЦ ЦИТИРОВАНИЯ}

Golyak, S.A. Evaluation and Research Experience of the Operational Control of Magnitogorsk Heat Suppply System / S.A. Golyak // Вестник ЮУрГУ. Серия «Компьютерные технологии, управление, радиоэлектроника». - 2017. - Т. 17, № 4. - С. 37-46. DOI: $10.14529 /$ ctcr 170405

\section{FOR CITATION}

Golyak S.A. Evaluation and Research Experience of the Operational Control of Magnitogorsk Heat Suppply System. Bulletin of the South Ural State University. Ser. Computer Technologies, Automatic Control, Radio Electronics, 2017, vol. 17, no. 4, pp. 37-46. DOI: $10.14529 /$ ctcr170405 